\title{
SOME FACTORS AFFECTING THE PREVALENCE
}

\section{OF STAMMERING}

\author{
BY \\ J. W. MCCULLOCH \\ Medical Research Council, Unit for Research on the Epidemiology of Psychiatric Illness, Department of Psychological \\ Medicine, University of Edinburgh, \\ AND \\ P. G. FAWCETT \\ Department of Psychological Medicine, University of Edinburgh
}

Stammering occurs throughout the civilized world and there has been no lack of theories to account for it. Most theories, and they have been well reviewed by Hahn (1943) and Diehl (1958), assume that there is only one important causative factor whether it be organic or psychological. The organic theories implicate cerebral dominance (Travis, 1931; Orton, 1937) supported by electro-encephalogram findings (Jasper, 1937) and genetic studies (Jameson, 1955). Biochemical investigations including endocrine studies have been unproductive (Hill, 1944). Psychoanalysts (Coriat, 1943) have viewed stammering as a specific form of neurosis attributable to pre-genital libidinal fixation. Despert (1943) and West (1943) suggest that an abnormal maternal attitude is one of the most important causes. Johnson and his associates (1959) consider that physical and hereditary factors are of only minor aetiological significance; they have produced a multi-dimensional theory in which stammering is seen as learned behaviour arising early in life when the neuromuscular speech patterns are developing. According to Johnson and others (1959), Despert (1943), and West (1943), certain parental characteristics are important in the aetiology of stammering in children. They found that the mothers of stammering children had higher and more strict standards of behaviour for their children and were more dissatisfied with their actual behaviour. The mothers seemed more discontented, more striving, more perfectionistic, and more concerned about what their neighbours thought of them than were the parents of control groups. They demanded higher standards of speech than did other parents. The striving for excellence and the associated feelings of dissatisfaction or failure were found to be more prominent in the mothers than in the fathers of stammering children, the fathers tending to adopt a more conciliatory role.

If psychological factors are important in causing stammering, the prevalence might be expected to vary in different sub-cultures; moreover, any observed differences in prevalence might be related to social and psychological differences between stammerers and their families on the one hand, and non-stammerers and their families on the other. The purpose of the present study is to explore these possibilities.

Previous clinical observations had been made by the authors on adults referred to the Royal Infirmary of Edinburgh for the treatment of stammering. The stammerers, who were mostly males, developed anxiety and stammered more in situations in which they felt their social status was challenged. They disclosed characteristic attitudes which apparently arose out of particular family relationships. Similar observations had been reported by West (1943), Despert (1943), and Johnson and others (1959). The mothers of the patients were often socially insecure with high social aspirations, over-perfectionistic, and anxious about discipline. These characteristics were clearly displayed in relationships with their children. The fathers generally assumed a more passive role and tended to avoid conflict by acquiescing in the demands of the mothers. We endeavoured to repeat these clinical observations in a whole population survey.

\section{MethoD}

All primary school children in local authority schools in the counties of Moray, Nairn, and Banff were studied. The counties comprise three types of community; fishing towns and villages, other rural 
areas (generally extremely isolated), and small commercial towns. For the purpose of the study, towns with a population exceeding 3,000 where occupations were varied were considered "urban commercial"; towns with populations exceeding 3,000 where the basic industry was fishing were considered "urban fishing"; places with populations less than 3,000 where fishing was the main source of livelihood were considered "rural fishing"; all other areas with populations under 3,000 were considered "rural farming". There was one exception: Kinloss, with a population of under 3,000 , has a large RAF station with a population far exceeding that of the village, and was classed as "urban commercial" instead of "rural farming" since the members of the local school population were not really the children of rural dwellers.

The marked cultural differences in these areas have been described in "The Third Statistical Account of Scotland", vol. 10, "The County of Banff" (Scottish Council of Social Service, 1961).

Progress has been so rapid in the commercial towns that they now differ from the larger Scottish cities and towns in little but size. The fishing towns and villages retain many century-old characteristics and are still greatly influenced by the state of the fishing industry. In the fishing areas kinship bonds are still strong and religion plays a much greater part in both family and community life, particularly in the areas which come under the influence of the "Close" and "Open" Brethren, where severe Calvinistic morality contrasts sharply with standards found elsewhere. Extreme religious groups are required to reject most forms of entertainment and not even to participate in the established political and educational life in the community. In this atmosphere parental control is inevitably stricter, more perfectionistic, and more concerned about neighbourhood values. Social striving is still present and is manifest by the obvious show of acceptable symbols of wealth. "Like the monks of old, they renounce the world and its pleasures, but unlike them they take no vows of poverty" (Robinson, 1945). Religion also plays a much more influential part in the farming areas than in the towns and the evidence of change is not nearly so marked. Despite substantial material advancement many of the rural dwellers are still awkward and self-conscious in the towns.

Mothers in both rural and fishing areas are intensely concerned that their children should better themselves but the possibilities for betterment are limited by a lack of local industry. Consequently, there is a high premium on educational success as a means of achieving advancement. If, as Johnson and others (1959), Despert (1943), and West (1943) suggested, the mothers of stammering children have higher and stricter standards of behaviour and are more striving and more perfectionistic, one would expect to find a higher prevalence of stammering in areas where the general standards of behaviour are more perfectionistic and strict, where children come more closely under the influence of parents because of greatly limited peer-group activities, and where striving for success is restricted by lack of local industry. We believed that this would hold good for the fishing and rural areas of Moray, Nairn, and Banff. We believed also that, by comparing these areas with an urban commercial area where standards are less stringent, where parental influence is lessened by greater peer-group activity, and where there is more available and greater choice of occupation, differences in the prevalence of stammering would be demonstrated and that these differences would be due to the different psychological and social influences to which the children were subjected.

The study was restricted to primary school children because the literature indicated that stammering normally begins between the ages of 3 and 5 years and often disappears after the age of 11 or 12 years. Secondary schools were not included because they are almost always located in the towns and the teachers know less about the parents and because of the problems involved in obtaining controls from the same area of residence. All information about the families was obtained from the teachers.

With the co-operation of the Directors of Education of HM Inspector of Schools, all head teachers were asked to estimate the amount of speech defect in their respective schools. The replies indicated that there were enough cases and a sufficient variation to justify the study. Class teachers were then asked to complete a questionnaire for each child who stammered and for the next child of the same sex on the register who did not stammer, with the following information; name, address, date of birth, father's occupation (and, where applicable, his absences from home for occupational or other reason), sibship size, position of the child in the sibship, estimate of the child's personal tidiness. The child's intelligence, measured or estimated, was given together with an account of the mother's attitude to the child in terms of aspiration and education. Lastly, teachers were asked to describe the mother's personality and to make any other comment.

The questionnaire was designed to elicit answers from the teachers in their educational rather than in their lay capacities. One question called for a personality description of the mother, but teachers supplied information regarding family and inter- 
personal relationships without specific questioning. Though there were differences in the quality of this information, it was given because the teachers felt it to be important. They were unaware of our hypotheses and, indeed, had no contact with us until after the completion of the questionnaires. The completed forms were returned to $\mathrm{HM}$ Inspector of Schools, who assigned each pair to its appropriate area, i.e. urban commercial, urban fishing, rural farming, or rural fishing. Though he was unaware of our hypotheses, his help had been enlisted, because of his local knowledge, to define the areas before the questionnaires were compiled. The questionnaires were sent to us together with the total number of pupils in each school.

We then interviewed 85 per cent. of the subjects (stammerers) and controls (next pupil) in order to verify that the subjects stammered and the controls did not, to obtain further information about the children, and to gather as much local knowledge as possible from teachers and other sources. Any additional subjects discovered were added to this study and all children about whose speech there was some doubt were examined.

We compared our assessments with those of the two speech therapists for the area. With two exceptions our findings tallied, and since there was a discrepancy of less than 2 per cent. between what we called stammering, what the teachers called stammering, and what the speech therapists called stammering, we accepted that the remaining 15 per cent. of the subjects were stammerers because the therapists agreed with the teachers. The speech therapists and in some cases we ourselves confirmed the absence of stammerers in the schools making nil returns.

The Director of Education for the City of Edinburgh kindly supplied data about the prevalence of stammering in children in local authority schools in the City to permit further cultural comparison.

\section{FINDINGS}

The total population of 12,448 primary school children (males 6,428: females 6,020) yielded 102 children who stammered (males 87: females 15; male : female ratio $5 \cdot 8: 1$ ). The distribution by area is shown in Table $\mathbf{I}$.

Prevalence by Sex, Age, and Area

For boys the urban commercial areas have significantly fewer stammerers than all other areas $\left(\varkappa^{2}=5 \cdot 446 ; \mathrm{P}<0 \cdot 02 ; 1 \mathrm{~d} / \mathrm{f}\right)$.

The Figure shows that the prevalence of stammering rises with age in both the northern population and in Edinburgh.

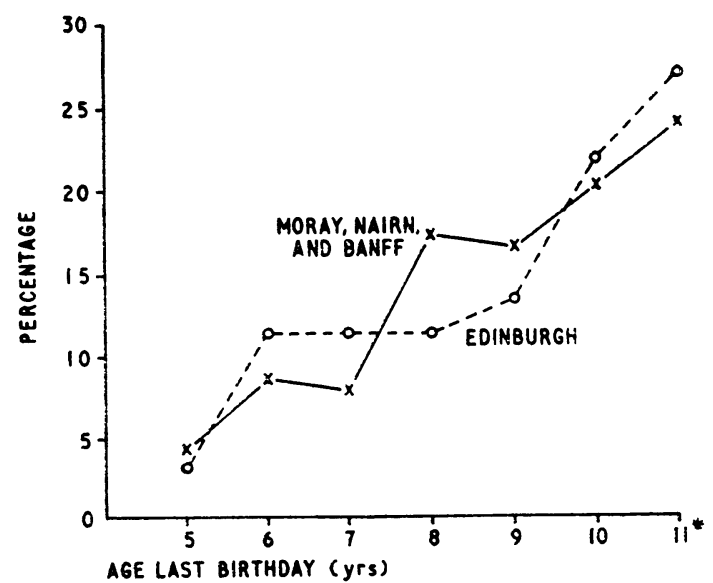

Ficiure.-Poinc presalence rate of stammering anongst primary schoo! children. 1963.

* A very few children included here in both numerator and denom . nator had passed their 12th birthday.

The prevalence rate does not vary with the size of the school for schools with fifty or more pupils, but schools with fewer than fifty pupils yielded twice the rate for all schools. This difference is highly significant (Table II, opposite) and persists even when urban schools are excluded (Table III, opposite).

We did not know about school size until the data were in our possession, but we feel that it helps to demonstrate the higher prevalence rates in rural areas since schools with fewer than fifty pupils

TABLE I

DISTRIBUTION BY AREA AND SEX

\begin{tabular}{|c|c|c|c|c|c|c|c|}
\hline & \multirow{2}{*}{ Area } & \multicolumn{3}{|c|}{ Males } & \multicolumn{3}{|c|}{ Females } \\
\hline & & $\begin{array}{l}\text { No. of } \\
\text { Pupils }\end{array}$ & $\begin{array}{c}\text { No. of } \\
\text { Stammerers }\end{array}$ & $\begin{array}{l}\text { Rate per } \\
1,000\end{array}$ & $\begin{array}{l}\text { No. of } \\
\text { Pupils }\end{array}$ & $\begin{array}{c}\text { No. of } \\
\text { Stammerers }\end{array}$ & $\begin{array}{c}\text { Rate per } \\
1.000\end{array}$ \\
\hline Urban & $\begin{array}{l}\text { Fishing } \\
\text { Commercial }\end{array}$ & 1,122 & $\begin{array}{l}19 \\
22\end{array}$ & $\begin{array}{r}16 \cdot 9 \\
9 \cdot 2\end{array}$ & $\begin{array}{l}1.080 \\
2.166\end{array}$ & $\begin{array}{l}1 \\
3\end{array}$ & $\begin{array}{l}0.9 \\
1.4\end{array}$ \\
\hline Rural & $\begin{array}{l}\text { Fishing } \\
\text { Farming }\end{array}$ & $\begin{array}{r}652 \\
2,256\end{array}$ & $\begin{array}{l}10 \\
36\end{array}$ & $\begin{array}{l}15 \cdot 3 \\
16 \cdot 0\end{array}$ & $\begin{array}{r}688 \\
2,086\end{array}$ & $\begin{array}{l}4 \\
7\end{array}$ & $\begin{array}{l}5 \cdot 8 \\
3 \cdot 4\end{array}$ \\
\hline Total & $\ldots \quad \ldots$ & 6.428 & 87 & $13 \cdot 5$ & 6,020 & 15 & $2 \cdot 5$ \\
\hline
\end{tabular}


TABLE II

SCHOOL SIZE-ALL SIZES

\begin{tabular}{c|c|c|c|c}
\hline $\begin{array}{c}\text { No. on } \\
\text { School Roll }\end{array}$ & $\begin{array}{c}\text { No. of } \\
\text { Schools }\end{array}$ & $\begin{array}{c}\text { No. of } \\
\text { Pupils } \\
\text { at Risk }\end{array}$ & $\begin{array}{c}\text { No. of } \\
\text { Stammerers }\end{array}$ & $\begin{array}{c}\text { Prevalence } \\
\text { per 1,000 }\end{array}$ \\
\hline$<50$ & 40 & 1,147 & 21 & 18 \\
$50-$ & 21 & 1,343 & 11 & 8 \\
$100-$ & 7 & 871 & 10 & 11 \\
$150-$ & 7 & 1,188 & 12 & 10 \\
$200+$ & 19 & 7,899 & 48 & 6 \\
\hline Total .. & 94 & 12,448 & 102 & 8 \\
\hline
\end{tabular}

$\chi^{2}$ Schools $<50 \times$ All Others $=15.904 ; \mathrm{P}<\cdot 0001 ; 1 \mathrm{~d} / \mathrm{f}$.

TABLE III

SCHOOL SIZE IN RURAL AND FISHING AREAS

\begin{tabular}{c|c|c|c|c}
\hline $\begin{array}{c}\text { No. on } \\
\text { School Roll }\end{array}$ & $\begin{array}{c}\text { No. of } \\
\text { Schools }\end{array}$ & $\begin{array}{c}\text { No. of } \\
\text { Pupils } \\
\text { at Risk }\end{array}$ & $\begin{array}{c}\text { No. of } \\
\text { Stammerers }\end{array}$ & $\begin{array}{c}\text { Prevalence } \\
\text { per 1,000 }\end{array}$ \\
\hline$<50$ & 40 & 1,147 & 21 & 18 \\
$50-$ & 20 & 1,268 & 11 & 9 \\
$100-$ & 6 & 760 & 8 & 10 \\
$150-$ & 7 & 1,188 & 12 & 10 \\
$200+$ & 9 & 3,521 & 25 & 7 \\
\hline Total .. & 82 & 7,884 & 77 & 10 \\
\hline
\end{tabular}

$\chi^{2}$ Schools $<50 \times$ All Others $=10 \cdot 127 ; P<\cdot 002 ; 1 \mathrm{~d} / \mathrm{f}$.

typify remote areas. It also demonstrates that closer supervision in academic spheres may also be a factor to be considered in that teacher/pupil relationships in small schools tends to be much more personal.

\section{INTELLIGENCE}

In our study stammerers have a lower I.Q. than controls (using Kendall's non-parametric test of trend (Table IV) $T=-0.23 ; \quad P=0 \cdot 0009$ ). No I.Q.s were available for the stammerers in the Edinburgh schools, so that no comparison with the trend found in the north was possible. However, for Edinburgh, a comparison between normal schools and schools for the mentally handicapped shows a highly significant greater prevalence of stammering in the latter $\left(\chi^{2}=32.62 ; P=<0.00001 ; 1 \mathrm{~d} / \mathrm{f}\right)$.

Again, using Kendall's test of trend, there was no significant differences in intelligence between pupils (whether stammerers or controls) in urban commercial and other areas.

\section{Family Social Patterns (Table V)}

(i) High Aspiring Mother.-When compared with mothers of controls a significantly greater number of the mothers of stammerers had higher than average aspirations for their children.

(ii) Child's Personal Neatness.-A significantly greater number of the stammerers were above average in their personal neatness.
TABLE IV

INTELLIGENCE OF STAMMERERS AND CONTROLS

\begin{tabular}{|c|c|c|c|c|}
\hline Children & Area & $\begin{array}{c}\text { Above } \\
\text { Average } \\
\text { I.Q.>110 }\end{array}$ & $\begin{array}{c}\text { Average } \\
\text { I.Q. } 90-109\end{array}$ & $\begin{array}{l}\text { Below } \\
\text { Average } \\
\text { I.Q. }<90\end{array}$ \\
\hline Stammerers & $\begin{array}{l}\text { Urban Commercial } \\
\text { Rural and Fishing }\end{array}$ & $\left.\begin{array}{l}1 \\
8\end{array}\right\} 9$ & $\left.\begin{array}{l}14 \\
36\end{array}\right\} 50$ & $\left.\begin{array}{r}9 \\
20\end{array}\right\} 29$ \\
\hline Controls & $\begin{array}{l}\text { Urban Commercial } \\
\text { Rural and Fishing }\end{array}$ & $\left.\begin{array}{l}4 \\
8\end{array}\right\} 12$ & $\left.\begin{array}{l}19 \\
48\end{array}\right\} 67$ & $\left.\begin{array}{l}1 \\
8\end{array}\right\}$ \\
\hline
\end{tabular}

TABLE V

SOCIAL PATTERNS

\begin{tabular}{|c|c|c|c|}
\hline Social Criteria & $\begin{array}{l}\text { Stam- } \\
\text { merers } \\
\text { per cent. } \\
(n=102)\end{array}$ & $\begin{array}{l}\text { Controls } \\
\text { per cent. } \\
(n=89)\end{array}$ & $\begin{array}{l}\text { Signifi- } \\
\text { cance of } \\
\text { Difference } \\
\text { (P) }\end{array}$ \\
\hline $\begin{array}{l}\text { (i) High-Aspiring Mother ... } \\
\text { (ii) } \\
\text { (iii) Soctreme Personal Neatness } \\
\text { Family Disorganization in } \\
\text { Fam .. . }\end{array}$ & $\begin{array}{l}58 \\
44 \\
30\end{array}$ & $\begin{array}{r}11 \\
27 \\
9\end{array}$ & $\begin{array}{l}<0.0001 \\
<0.02 \\
<0.0003\end{array}$ \\
\hline
\end{tabular}

(iii) Social Disorganization.-There was a significantly higher incidence of social disorganization in the homes of the subjects than in the homes of the controls. In this context social disorganization was evidenced by such factors as financial difficulties, marital problems, and strained inter-personal relations, with, in some cases, ill-treatment of children. Many children from socially-disorganized homes had parents who were mentally ill, mentally subnormal, or markedly mentally unstable. All information referred to in this section was given in response to the question "any other comment". Because, in the field of psychological disorders, the teachers were lay observers, no qualification was possible. We therefore confined ourselves to using their descriptive terms.

Examples of teachers' reports indicating social disorganization were:

"Mother has a low I.Q. Unstable. A bad manager." "Unstable mother. Spoils child badly materially with great emotional neglect."

"Illegitimate child but mother later married then divorced. Remarried but now separated and awaiting second divorce."

"This child is in the care of the Local Authority because of parental cruelty."

"Mother attempts to cope with four small children in a small caravan and has to 'punish' them continually. Not a well-integrated personality and clearly finds it hard to manage her children."

Of the children from socially-disorganized families, 36 per cent. had I.Q.s lower than average compared with 33 per cent. of the total sample. 29 per cent. of 
the stammerers with I.Q.s of average or above came from socially-disorganized families. Ten stammerers who had mothers below average in aspirations and six stammerers who were below average in neatness came from socially-disorganized families yet did not have low I.Q.s. Social disorganization, therefore, seems to play a part in the genesis of stammering independently of low I.Q.

Familial OCCURRENCE.-Although this information was not sought specifically, a history of stammering in the immediate family was reported in 24 cases involving nineteen families. In each of the three sets of twins (ovularity uncertain) in the survey, only one child stammered.

Intensity of the Stammer.-The girls who stammered were without exception more seriously afflicted than the boys. We did not find any significant factors to account for this finding; social disorganization, however, was reported more often for girls (40 per cent.) than for boys ( 29 per cent.).

Miscellaneous.-There were no differences between the subjects and controls in respect of sibship size or ordinal position in the sibship. The fathers of subjects were somewhat, but not significantly, more often absent from home than fathers of controls.

A specific precipitating event was reported in 11 per cent. of the cases.

\section{Discussion}

Morganstern (1953) found that the prevalence of stammering per 1,000 in the primary schools of Edinburgh was $21 \cdot 2$ for males and $3 \cdot 6$ for females (Table VIa). Since our own Edinburgh findings were five times lower, we studied his method in detail to attempt to account for the discrepancy. His rates appeared to be derived only from observations of children in the oldest primary school age group of Edinburgh local authority schools. Since, as we have shown (Figure), this age group contains the highest number of stammerers both in the north and in Edinburgh, we have reason to believe that there were errors in the numerator and denominator of his prevalence equation which both acted to produce an excessive rate.

We then projected his rates for the oldest age group onto the whole Edinburgh school primary population at that time, using as a basis the age distribution of stammerers in Edinburgh which we obtained. The resultant corrected prevalence rates (Table VIb) are similar to those we found in the urban commercial areas in Moray, Nairn, and Banff. The projection from Morganstern's data yields a rather higher prevalence rate for Edinburgh than our 1962-63 figures (Table VIa), but when he supplied
TABLE VIa

STAMMERING PREVALENCE RATES PER 1,000 FOR PRIMARY SCHOOLS

\begin{tabular}{|c|c|c|c|c|c|}
\hline & \multirow[t]{2}{*}{ Area } & \multicolumn{3}{|c|}{ Sex } & \multirow{2}{*}{$\begin{array}{c}\text { Males } \\
\text { per } \\
100 \\
\text { Fe- } \\
\text { males }\end{array}$} \\
\hline & & Males & $\begin{array}{c}\mathrm{Fe}- \\
\text { males }\end{array}$ & $\begin{array}{l}\text { Both } \\
\text { Sexes }\end{array}$ & \\
\hline $\begin{array}{l}\text { Moray, Nairn, } \\
\text { and Banff }\end{array}$ & $\begin{array}{l}\text { Urban Fishing } \\
\text { Urban Commercial } \\
\text { Rural Fishing } \quad \ldots \\
\text { Rural Farming } \quad \ldots\end{array}$ & $\begin{array}{r}16 \cdot 9 \\
9 \cdot 2 \\
15 \cdot 3 \\
16 \cdot 0\end{array}$ & $\begin{array}{l}0 \cdot 9 \\
1 \cdot 4 \\
5 \cdot 8 \\
3 \cdot 4\end{array}$ & $\begin{array}{r}9 \cdot 1 \\
5 \cdot 5 \\
10 \cdot 5 \\
9 \cdot 9\end{array}$ & $\begin{array}{r}1,820 \\
664 \\
264 \\
475\end{array}$ \\
\hline Edinburgh & $\begin{array}{l}\text { 1962/63 Data } \\
\text { Morganstern (1953) }\end{array}$ & $\begin{array}{r}4 \cdot 0 \\
21 \cdot 2\end{array}$ & $\begin{array}{l}1 \cdot 0 \\
3 \cdot 6\end{array}$ & $\begin{array}{r}2 \cdot 5 \\
12 \cdot 5\end{array}$ & $\begin{array}{l}391 \\
588\end{array}$ \\
\hline
\end{tabular}

TABLE VIb

COMPARISON OF PREVALENCE RATES OF PRESENT STUDY WITH THOSE OF MORGANSTERN (1953)

\begin{tabular}{|c|c|c|c|c|}
\hline \multirow{2}{*}{ Area } & \multicolumn{3}{|c|}{ Sex } & \multirow{2}{*}{$\begin{array}{c}\text { Males } \\
\text { per } \\
100 \\
\text { Fe- } \\
\text { males }\end{array}$} \\
\hline & Males & $\begin{array}{c}\mathrm{Fe}- \\
\text { males }\end{array}$ & $\begin{array}{c}\text { Both } \\
\text { Sexes }\end{array}$ & \\
\hline $\begin{array}{l}\text { Moray, Nairn, and Banff- } \\
\text { Urban Commercial } \\
\text { Morganstern (1953) adjusted to } \\
\text { Edinburgh 1962-63 Age } \\
\text { Distribution }\end{array}$ & $9 \cdot 2$ & $\begin{array}{l}1 \cdot 4 \\
1 \cdot 7\end{array}$ & $5 \cdot 5$ & 664 \\
\hline
\end{tabular}

us with the number of stammerers for this year the Director of Education indicated that a number of the less severe cases were not included by the speech therapists who compiled the data.

The prevalence of stammering in the rural and fishing districts is clearly higher than in the urban commercial areas. We can find no evidence of a hereditary or a physical factor (such as a high incidence of minimal birth injury) peculiar to these areas to account for it. Although there is an association between stammering and low intelligence, we have found no positive association between low intelligence and rural school populations as a whole, nor have we been able to demonstrate any relationship between intelligence and area of residence in either stammerers or non-stammerers. The positive relationship between stammering and low intelligence cannot therefore account for the higher prevalence in the rural and fishing areas.

It seems most likely that family and cultural differences explain our findings, although conceivably there may be a genetically-conditioned predisposition towards stammering which is activated by environmental influences. Our findings support the findings of Johnson and others (1959), Despert (1943), and West (1943) regarding the prevalence among stammerers of high aspiring mothers and of personal neatness (Table V). There are also cultural peculiarities in the fishing and rural areas which may be responsible for the greater prevalence of stammering. In small rural schools with small classes, which 
we have shown to be associated with a high prevalence of stammering, teachers are able to give more individual attention to educational and speech development. One aim is to reduce the broad local dialects. Perhaps, therefore, in the rural areas, an educational process rather than the family exerts a particular influence on the child's speech. We have suggested that a particular parental influence might be related to the prevailing religion. This influence might be expected to be stronger in view of these children's relative isolation from wider social contacts. In the more remote areas teachers reported that many of their pupils were virtually isolated in the lonely farms and crofts, and older children were often expected to help on the farm so that peergroup activities were restricted even further. Therefore, if parental influences are important factors in the aetiology of stammering, they would be expected to be greater in isolated communities. Some confirmation of this hypothesis emerged in our interviews with the children, when we found that in the rural schools the boys tended to give their father's occupation as their own occupation of choice for the future, whereas in the urban commercial areas their choice of occupation was more varied and imaginative.

Our data provide support for the view that social and psychological factors play a role in the production of stammering and that these factors may be related to relatively strict methods of upbringing associated with anxiety and high parental aspiration. This finding is in agreement with that of Johnson and his associates (1959). We have shown, however, that a significant group of stammerers came from socially disorganized homes and families. These families were characterized by social stress, anxiety, and overt conflict unlike the apparently well-integrated families described by Johnson.

All the social variables set out in Table $\mathrm{V}$ were considered by area and the distribution for each showed no significant differences. For the stammerers there was a slight tendency for social disorganization to occur more frequently in the urban commercial area, so that this factor cannot be held to account for the higher prevalence in the rural and fishing districts. Using the control group to make comparison between the areas for each of the social variables did not demonstrate any significant differences, but the numbers were rather small for statistical treatment. In our findings low intelligence and social disorganization were not significantly related and may operate independently (Table V).

\section{SUMMARY}

The prevalence of stammering in all primary school children in the counties of Moray, Nairn, and Banff and in the city of Edinburgh is presented.

Personal and social data about stammerers and non-stammerers have been compared. The prevalence of stammering increased with age. The male : female ratio among stammerers varied in the different areas from $2 \cdot 6: 1$ to $18 \cdot 2: 1$. Stammering was found to be significantly more prevalent in fishing and rural farming areas than in the urban commercial areas. Stammerers had lower I.Q.s than controls, but there was no relationship between intelligence and area of residence. Mothers of stammering children had higher social aspirations than had mothers of controls. Stammerers were neater in their personal appearance and were more likely to come from socially-disorganized families. There were no differences in family size or sibship position. Fathers of stammerers lived apart from the family somewhat more often than fathers of controls. The bearing of these findings upon the aetiology of stammering is discussed.

We are indebted to Mr John J. Reid, HM Inspector of Schools, for his advice and practical help in organizing this study. Miss Gray, Speech Therapist for Banffshire, and Miss Fletcher, Speech Therapist for Moray and Nairn, gave valuable assistance in the ascertainment of stammering in their respective areas and we are grateful to them. We should also like to express our thanks to Mr W. F. Lindsay, Director of Education for Moray and Nairn, and Mr James McNaught, Director of Education for Banffshire, and all the teachers in both areas without whose co-operation the study would not have been possible.

\section{REFERENCES}

Coriat, I. H. (1943). Nerv. Child, $2,167$.

Despert, J. L. (1943). Amer. J. Orthopsychiat., 13, 517.

Diehl, C. F. (1958). "A Compendium of Research and Theory on Stuttering." Thomas, Springfield, Ill.

Hahn, E. F. (1943). "Stuttering: Significant Theories and Therapies." Stanford University Press, California.

Hill, H. (1944). J. Speech Dis., 9, 245; 289.

Jameson, A. M. (1955). Speech, 19, 60.

Jasper, H. H. (1937). Psychol. Bull., 34, 411.

Johnson, W., and Associates (1959). "The Onset of Stuttering." University of Minnesota Press, Minneapolis.

Morganstern, J. J. (1953). "Psychological and Social Factors in Children's Stammering." Ph.D. Thesis, Edinburgh.

Orton, S. T. (1937). "Reading, Writing, and Speech Problems in Children." Norton, New York.

Robinson, W. (1945). "The Shattered Cross." Berean Press, Birmingham.

Scottish Council of Social Service (1961). "Third Statistical Account of Scotland", vol. 10, "The County of Banff", ed. H. Hamilton for The University of Aberdeen, chapters 2, 4, 6, 8. Collins, Glasgow.

Travis, L. E. (1931). "Speech Pathology", Appleton, New York.

West, R. (1943). Nerv. Child, 2, 96. 